\title{
STUDY OF BACTERIAL ASSOCIATED WITH KOLANUT SOIL PLANTATION AND WASTE LOOKING AT THEIR BENEFITS TO MAN AND HIS ENVIRONMENT
}

\author{
T. B. Fabunmi ${ }^{1}{ }^{*}$, D. J. Arotupin ${ }^{2}$ and D. V. Adegunloye ${ }^{3}$ \\ 1, 2, 3 Dept. of Microbiology, Federal University of TeChnology, P. M. B. 704 AKure, Ondo State, NigERIA. \\ E-mail addresses: 1tbfabunmi@gmail.com, ${ }^{2}$ djarotupin@futa.edu.ng, ${ }^{3}$ dvadegunloye@futa.edu.ng
}

\begin{abstract}
Microorganisms are regarded as the oldest and most abundant life form on earth and their importance to man cannot be over emphasized. They are the occupants and architect of the biosphere maintaining metabolic cycles essential for life. The aim of the study was to explore the benefits and detriments of bacteria associated with kolanut soil plantation and waste to man and the environment. Bacterial was isolated from kolanut soil plantation, decayed, decaying and fresh kolanut waste (testa and husk) obtained from Ilara-Mokin (Ondo State) and Owena-Osun (Osun State), Nigeria following standard procedures. Thirteen isolates with distinctive morphological and physiological characteristics were identified using molecular techniques and Sanger sequencing was employed to detect labelled chain-terminating nucleotides that are incorporated by DNA polymerase during replication of the templates. The genus of bacteria identified included; Bacillus, Enterobacter, Citrobacter, Klebsiella, Pseudomonas, Marinobacter, Staphylococcus, Lysinibacillus, Providencia, Erwinia. The most dominant genus however was the Bacillus, Pseudomonas and Citrobacter. A good number of the bacteria isolated can be explored for production of products such as enzymes, use as biocontrols and for environmental cleanups.
\end{abstract}

\section{Keywords: Microorganisms, Kolanut waste, Soil, Biocontrols, Environment, Benefits}

\section{INTRODUCTION}

The oldest and most abundant life form on planet is bacteria and their phages. They are the governing occupants and architect of the entire biosphere, sustaining the metabolic cycle essential for life on earth [1].Microorganisms are essential to man and the survival of the ecosystem at large. Over the years, they have been explored by man in the fields of medicine, agriculture, food and textile industries. The ability to study microbial community with its complexity and functions as a whole has been made easier by recent technological advances such as next-generation sequencing, metagenomics, genomics, proteomics and transcriptomics [2]. Even though these techniques provide unprecedented access to genomic potentials, gene regulation, expression and function in situ, Nigeria is one of many developing countries lagging behind in these technologies. Nigeria has the arid land which supports numerous microbial communities in addition with the agricultural wastes generated from agricultural practices but the technology is not readily available to explore the microbial world effectively and efficiently.
Most environment harbors an exquisite diverse collection of microbial species which compete with their neighbors for space and resources. Microorganisms have mechanisms by which they can impair or kill other microbes and interactions between and within bacterial species can profoundly impact the outcome of competition [3]. The human race has plunged deeply into natural resources and as it is at present, development path is not sustainable. A major reason for this is connected to a growing population in an interconnected but unequal and human-dominated world which is undermining the Earth's essential lifesupport systems without replacing it. A response to the situation is through science and awareness across many disciplines and countries of the need for synthesis and integration, which is being reflected in development of multidisciplinary research efforts and institutions [4]. The use of biotechnological tools has made the use of microorganisms for production of useful substances to man and conversion of waste easier and interesting. Scientific efforts such as use of by-products from microorganisms can be used to promote the goals of a sustainability which will meet 
human needs while preserving the life support systems of the earth.

\section{MATERIALS AND METHODS}

\subsection{Sample Collections}

Kolanut husk, kolanut testa and kolanut plantation soil were collected (irrespective of the kolanut specie) from kolanut farm located in Owena-Ijesha, Osun State and Ilara-Mokin, Akure, Ondo state, Nigeria. The samples were transported down to Department of Microbiology, The Federal University of technology, Akure in a Ziploc bag for analysis.

\subsection{DNA Extraction}

The DNA was extracted using the Fungal Bacterial DNA Zymo Research extraction kit supplied by Inqaba, South Africa. The extraction was carried out according to manufacturer's procedure.

\subsection{DNA Quantification}

The purity and quantity of DNA was determined using Nano-drop 1000 spectrophotometer (model no: ND 1000 UV/VIS- 1844; make: USA). The machine measures DNA quantity in $\mathrm{ng} / \mu \mathrm{l}$ and DNA purity at 260/280 $\mathrm{mm}$ absorbance.

\subsection{S rRNA Amplification}

The 16S rRNA region was amplified using the $27 \mathrm{~F}$ and 1492R primers on ABI 9700 Applied Biosystems thermal cycler at a final volume of 50 microliters for 35 cycles. The PCR conditions were as follows: Initial denaturation, $95^{\circ} \mathrm{C}$ for 5 minutes; denaturation, $95^{\circ} \mathrm{C}$ for 30 seconds; annealing, $52^{\circ} \mathrm{C}$ for 30 seconds; extension, $72^{\circ} \mathrm{C}$ for 30 seconds for 35 cycles and final extension $72^{\circ} \mathrm{C}$ for 5 minutes. The product was resolved on a $1.5 \%$ agarose gel at $120 \mathrm{~V}$ for 15 minutes and visualized on a UV trans illuminator.The band sizes were estimated by comparison with $1000 \mathrm{bp}$ molecular weight marker (Quick-Load DNA molecular ladder).

\subsection{Primer Sequence}

The 16S rRNA region of the isolate's DNA was amplified using the $27 \mathrm{~F}$ and $1492 \mathrm{R}$ primers $27 \mathrm{~F}$ AGAGTTTGATCCTGGCTCAG and 1492RCGGTTACCTTGTTACGACTT.

\subsection{Sequencing}

Sequencing was done using the BigDye Terminator kit on a 3510 ABI sequencer by Inqaba, Pretoria South Africa.

\subsection{Phylogenetic tree}

The evolutionary history was inferred by using the Maximum Likelihood method based on the JukesCantor Model [5]. Evolutionary analyses were conducted in MEGA7.

\section{RESULTS AND DISCUSSION}

A variety of microorganisms have been observed to dominate different environment based on their adaptation abilities. One of the species of Bacillus isolated in this work was Bacillus thuringiensis. Bacillus thuringiensis is a Gram-positive rod, anaerobic, spore forming saprophytic bacterium considered to be a variety of Bacillus cereus [6]. The organism was isolated in fermenting decayed/fresh kolanut husk and plantation soil. Bacillus is a well-known indigenous and persistent bacterial to the soil environment $[7,8]$. Bacillus thuringiensis occurs as a normal flora in the gut of caterpillars such as moths and butterflies, on leaf surfaces, aquatic environments, animal feces, insectrich environments, flour mills, deciduous and grain storage tanks $[9,10,11]$. Researchers such as Staley et al. [12], Roh et al. [13], Steinhaus [14] have all reported the isolation of this bacterium from different sources. Bacillus thuringiensis is nontoxic to people, pets and wildlife but the protein produced in them is toxic to insects. The toxin paralyzes insect's digestive system causing the insect to stop feeding within hours resulting in its death. This potential of the organism can be explored for production of biocontrol in large quantities since bacteria are generally known to be fast growers. Bacillus thuringiensis are also known to be protease producers, and the proteases have been used in processing inactive protoxins [15]. However, this organism is among the most difficult to classify due to its physiological characteristics and morphology [16]. In order to correctly classify microorganisms generally, it is important to adopt the molecular method of identification because it is more accurate and reliable than the conventional method of which classification made is dependent on the number and types of biochemical test carried out.

Enterobacter ludwigii is another bacterium isolated in the course of isolation from decaying husk, testa and fermented fresh husk, belonging to the genus Enterobacter and characterized as a Gram-negative fermentative microorganism with motile rod [17]. Hoffmann et al. [18] documented habitats from which Enterobacter ludwigii could be found and among the sources listed were; blood, urine, tissue fat, elm tree and other plant types. Enterobacter ludwigii was described by Paauw et al. [19] to be an Enterobacter cloacae complex type of specie. This particular group 
has been regarded to be of clinical significance, other related species in this group included; E. cloacae, E. asburiae, E. hormaechei, E. kobei and E. nimipressuralis [20]. Among these species, E. ludwigii has been reported to be isolated from clinical specimens and nominated as a new species in $2005[18,21]$. One of the sources of isolation of this particular bacterium was decaying kolanut husk and testa from farm site. The bacterium could have colonized the waste from the soil during decay as source of nutrient. Unavailability of lavatory on farm sites result in defecating on farm lands by farmers and by so doing release such microorganism into the environment. This calls for proper environmental management as some of the microorganisms discharged with human waste are pathogenic. During raining season, there will be runoff of such human waste into water bodies from which the farmers themselves and animals around drink from.

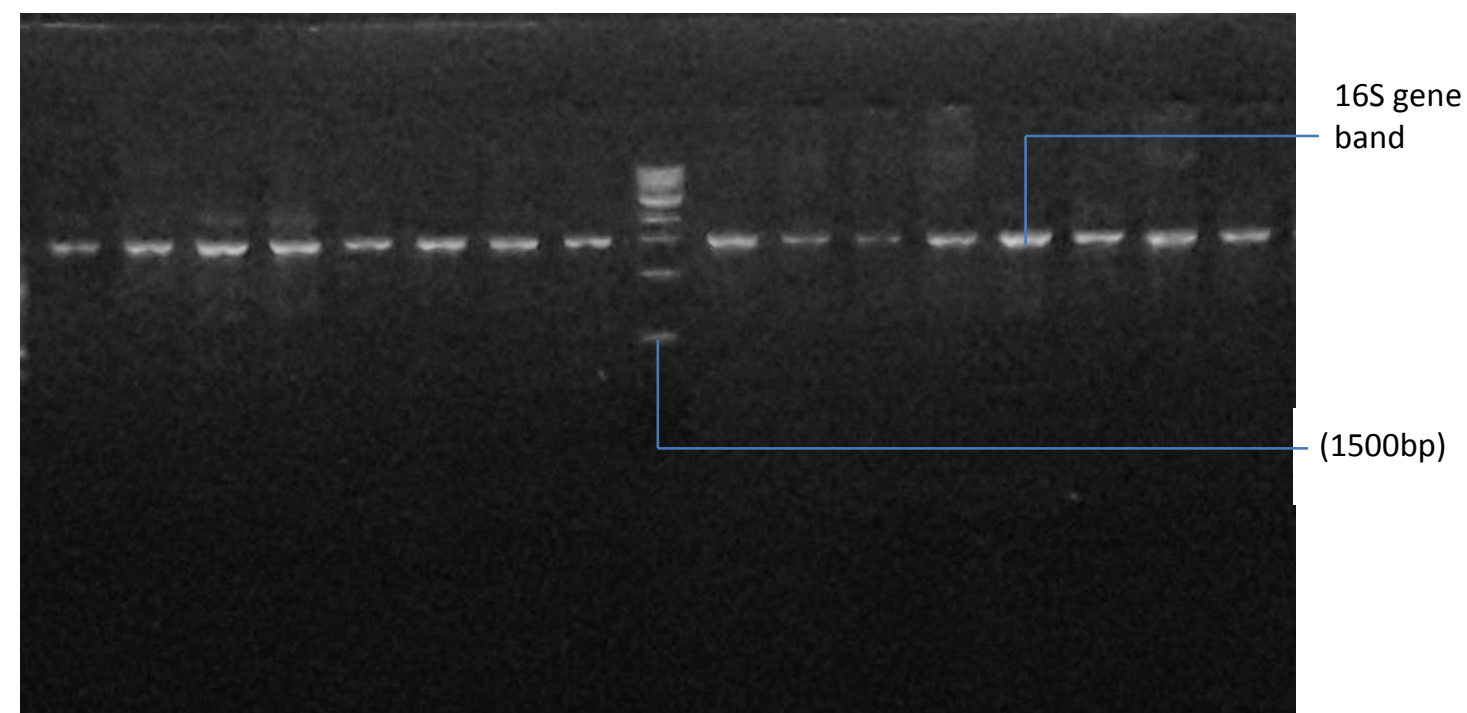

Fig 1: Agarose gel electrophoresis picture showing the 16S rRNA gene band (1500bp) of isolates. Lane 1-8 and 9-16 represents the isolates while lane M represents Quick-Load $1 \mathrm{~kb}$ DNA ladder.

Table 1: List of isolated bacteria and strain with the gene bank/accession number

\begin{tabular}{cll}
\hline S/NO & Identity by bacteria molecular method & Gene bank/accession number \\
\hline 1 & Bacillus thurigensis strain TB8 & gi/1366793970|MH085464.1 \\
2 & Enterobacter ludwigii strain TB9 & gi/1366793971|MH085465.1 \\
3 & Citrobacter amalonaticus strain TB1 & gi/1366793963|MH085457.1 \\
4 & Klebsiella oxytoca strain TB11 & gi/1366793973|MH085467.1 \\
5 & Pseudomonas stutzeri strain TB12 & gi/1366793974|MH085468.1 \\
6 & Citrobacter amalonaticus strain TB10 & gi/1366793972|MH085466.1 \\
7 & Marinobacter shengliensis strain TB13 & gi/1366793975|MH085469.1 \\
8 & Bacillus niacini strain TB2 & gi/1366793964|MH0885458.1 \\
9 & Pseudimonas putida strain TB3 & gi/1366793965|MH085459.1 \\
10 & Staphylococcus succinus strain TB4 & gi/1366793966|MH085460.1 \\
11 & Lysinibacillus sphaericus strain TB5 & gi/1366793967|MH085461.1 \\
12 & Providencia rettgeri strain TB6 & gi/1366793968|MH085462.1 \\
13 & Lysinibacillus fusiformis strain TB7 & gi/1366793969|MH085463.1 \\
\hline
\end{tabular}




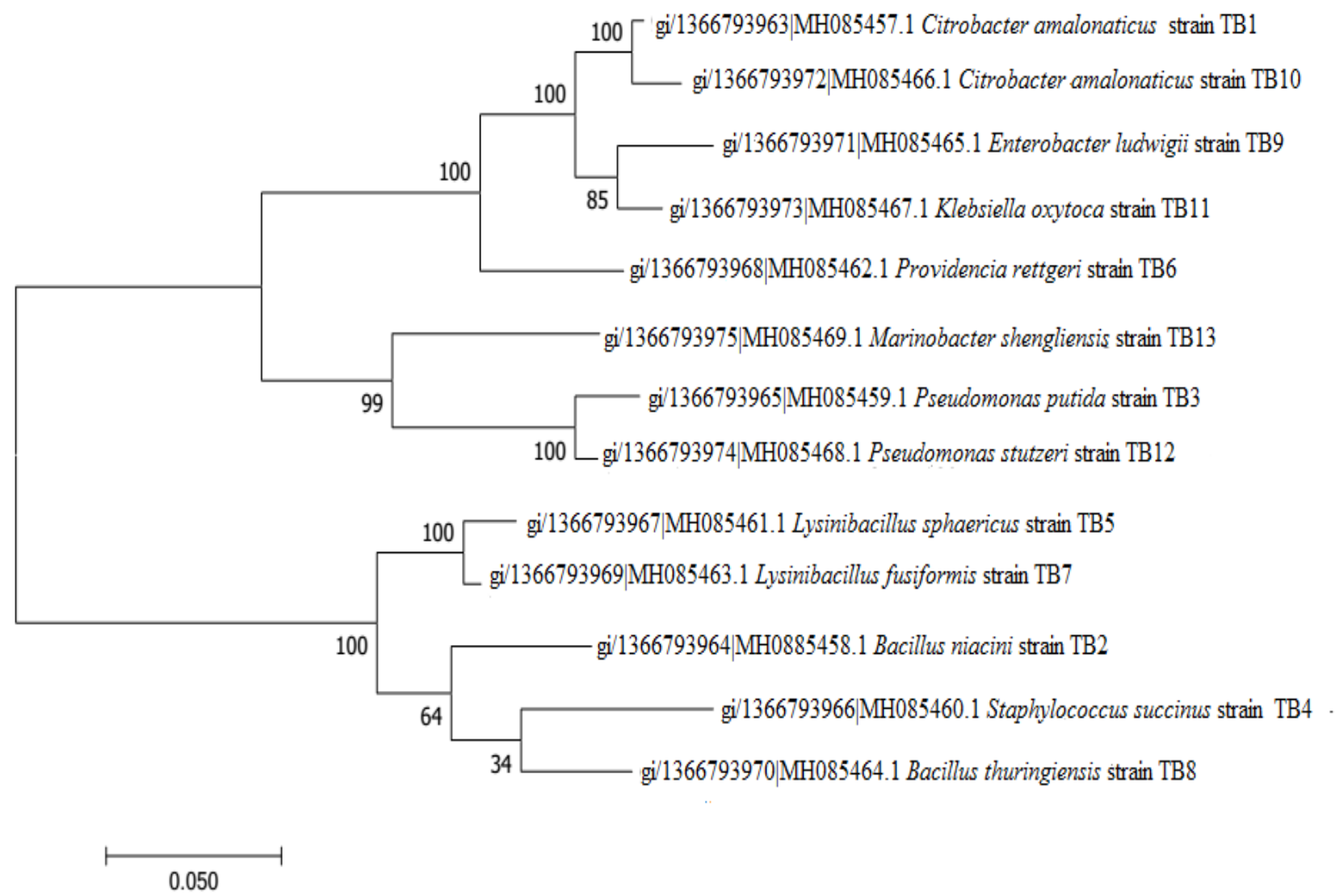

Figure 2: Molecular Phylogenetic analysis by Maximum Likelihood method of isolated bacteria from kolanut soil plantation and wastes

Citrobacter amalonaticus isolated from decaying kolanut husk from farm site and surface soil from kolanut plantation farm was shown to be categorized as a Gram- negative, rod-shaped bacterium, which uses citrate as its sole carbon source. Other sources from which the bacterium can be isolated from as reported by Don and Farmer [22] included; soil, water, sewage, food, faeces, intestine, urine clinical samples and in animals such as bat. In bats, Whitaker et al. [23] reported that Citrobacter amalonaticus have ability to breakdown chitin from partially digested insects. This makes them unique because no other vertebrate naturally has enzyme that can breakdown chitin found in insects. This microorganism can be harnessed for production of chitinase enzyme which could be used for example, in breaking down cell wall of fungus known to be more rigid as compared to that of bacterium. Another potential of the bacterium documented by other researchers is its ability to accumulate metals from the environment. When organic phosphates are available, the bacterium is able to break them down and use phosphate to attract metal ions in its environment even in small concentrations.
This bacterium is useful in the removal of uranium and other harmful materials from contaminated water or soil $[24,25]$. Klebsiella oxytoca a Gram-negative, rod shaped bacterium isolated predominantly from kolanut waste in the study. It is closely related to Klebsiella pneumoniae with ability to colonize plant hosts and fix atmospheric nitrogen into forms which plants can utilize. According to Raikher et al. [26], Klebsiella oxytoca can be found in a wide range of environment because they are ubiquitous and opportunistic in nature. The bacterium has been documented to have importance such as ability to mineralize iron salt solution to produce ferrihydrite nanoparticles and was determined to have magnetic properties useful in bioengineering and nanomedicine. In addition to this, it has the ability to breakdown cyanide a chemical extremely toxic to humans $[26,27]$. Some waste water contain cyanide, and treatment of this waste before discharge in to the environment makes use of methods such as alkaline chlorination and wet air oxidation which have been reported to be extremely expensive and reagents used are hazardous. Since Klebsiella oxytoca has been shown to have ability to degrade 
$1 \mathrm{mM}$ cyanide into ammonia they can be used to replace the use of chemicals [27]. This calls for researchers to look into the molecular aspect of this bacterium's performance.

Pseudomonas stutzeri was isolated from kolanut wastes and plantation soil however their populations differ. It is as Gram-negative, rod-shaped bacterium known for its diverse metabolism with a single polar flagellum [17]. Soil and marine waters are two major environments researchers have found Pseudomonas stutzeri to inhabit. In soil, the organism is found on the rhizosphere of growing plants while in the marine environment, it resides in the water column and sediment as reported by Lalucat et al [28]. Due to the ability the bacterium has, it can inhabit diverse environments, carry out extensive range of metabolic functions and play important role in nitrogen cycle [28, 29]. Chen et al. [30] reported the organism's applicable in bioremediation and waste water treatment due to its ability to metabolize a wide range of substrates. The microorganism is able to achieve this by natural transformation which allows for access to nutrient from the environment, absorb the nutrient into the cell and integrate it into its genome. This mechanism is suggestive to be what gives them ability to adapt quickly to changing environmental conditions and contribute to its vast distribution. Marinobacter shengliensis was isolated majorly from kolanut plantation soil. It is known to be a Gram-negative, moderately halophilic, aerobic, motile and rodshaped bacterium from the genus Marinobacter with a single polar flagellum. Glucose fermentation, Indole production and nitrate reduction are some of the characteristics this organism has. Acid is not usually produced from fructose, lactose, maltose, mannitol and sucrose. The bacterium was first isolated from Shengli Oilfield in China, from where it obtained its name shengliensis. The organism shares similarities with $M$. vinifirmus, M. excellens and M. hydrocarbonoclasticus $[31,32]$. Other sources from which Marinobacter genus can be isolated includes; wastewater, hot spring [33], seawater [34], hydrothermal sediment [35], marine sediment, saline lake [36] and saline soil [37]. Bacillus niacini was isolated from kolanut waste and soil in the study with varying population counts. They are classified by Bergey's manual [17] as aerobic endospore forming rods which have a Gram variable reaction when the cells are grown on nicotinate agar. Their colonies on nutrient agar are about 3 to $5 \mathrm{~mm}$ in diameter, smooth and having light beige centers surrounded by translucent areas of variable extension. It grows best between $\mathrm{pH} 7$ and 8, temperature range of $10^{\circ} \mathrm{C}$ to $40{ }^{\circ} \mathrm{C}$ and all strains produce acid from fructose, galactose, glucose, maltose, sucrose, and xylose. Nagel and Andreesen [38] mentioned a distinguishing characteristic of Bacillus niacini as having ability to reduce nitrate to nitrite anaerobically. Pseudomonas putida is a Gram-negative, rod shaped, flagellated bacterium found in most soil and water habitats where there is oxygen. Just as recorded in this study, the bacterium was isolated from kolanut husk and majorly from the soil. Espinosa-Urgel et al. [39] reported its ability to colonize plant roots and during which a mutual relationship is created between the plant and the bacteria. This occurs in such ways that, the plant allows the bacterium access nutrients from its root and in turn, the organism induces growth of the plant and protects it from pathogens. This ability has made the bacterium useful in bioengineering research to develop biopesticides and improve plant health. Another intriguing potential of the bacterium is its ability to breakdown aromatic and aliphatic hydrocarbons, degrade organic solvents such as toluene and convert styrene oil to degradable plastic polyhydroxyalkanoates (PHA) which helps degrade polystyrene [40]. This is an indication that the bacterium has strong appetite for organic pollutants and can therefore be used as laboratory workhorse for research on bacteria-remediated soil processes. Pseudomonas putida has also been reported to interact with other organisms in the soil and one of such interactions is with Saccharomyces cerevisiae in the rhizosphere. Saccharomyces cerevisiae produces glucose and $\mathrm{pH}$ favorable to both organisms while Pseudomonas putida in turn protects the plant [41]. This is a good and economical way of protecting plants from diseases caused by pathogenic bacteria, fungi and viruses alike. It will be a good plant disease control mechanism because Shash [40] has documented the fact that Pseudomonas putida lack virulence genes. The bacterium will be able to withstand environmental stress due to its diverse control of proteins such as protein modification/repair, folding/stabilization, degradation of proteins, peptides, glycopeptides and presence of sideospores an iron chelating compound which allows the bacterium enhance some levels of iron and promote an active transport chain [42]. Staphylococcus succinus was isolated from the kolanut wastes fermenting medium and plantation soil. According to Bergey's manual [17], Staphylococcus succinus is a Gram-positive coccoid bacterium, VogesProskauer negative, phosphatase positive, acid and gas are produced from lactose and mannose but cannot reduce nitrate to nitrite. However, they are regarded as 
difficult and ambiguous to classify because no clear biochemical test are available for accurate identification and characterization. It has been isolated from fermented and fresh sausages, cheese and skin of healthy wild animals [43]. Staphylococcus succinus was first described in 1998 and isolated from 35million year old Dominican amber [44, 45]. Staphylococcus succinus role in pathogenesis has not yet been clarified [46].

Isolate of Lysinibacillus sphaericus was obtained from kolanut waste and plantation soil in the study. They are Gram-positive, mesophilic, facultative anaerobe, rod shaped bacterium which can form dormant endospores to resist heat, chemicals and ultraviolet light also with able to metabolize polysaccharides [47]. Lysinibacillus sphaericus will hence undergo metabolism and growth only when the conditions are favourable and proper nutrients are available. However, there is a unique ability associated with Lysinibacillus sphaericus which is, the release of toxin into the gut of mosquito larvae thus causing the larvae to stop eating resulting in its death. In general the bacteria have an excellent capability to control Culex and Psorophora but less effective against Aedes, Mansonia and Ochlerotatus [48]. Lysinibacillus sphaericus is regarded as a common environmental organism which produces insecticidal toxin similar to that produced by Bacillus thuringiensis. Interestingly, Lysinibacillus sphaericus is also known as Bacillus sphaericus, the genus change was proposed by Ahmed et al. [49] due to the distinctive peptidoglycan composition of the cell wall, phylogenetic and physiological analyses. Lysinibacillus sphaericus can be used as a starter component in yoghurt because it has probiotic properties such as anti-inflammatory properties. It can be used as starter culture because it is not significantly harmful to humans [50]. Providencia rettgeri is one of the numerous microorganisms isolated from kolanut plantation soil. It is a group of Gram-negative, motile bacterium belonging to the family Enterobacteriaceae. Providencia rettgeri was named after Rettger L.F an American bacteriologist who first isolated the organism in 1904. The bacterium is an opportunistic pathogen which causes urinary infection and other infections such as diarrhea and eye infection. Providencia rettgeri can be identified by its motility and its ability to produce acid from mannitol [51]. This characteristics where observed but was identified as Proteus mirabilis using conventional method instead of Providencia rettgeri obtained using molecular method.

Lysinibacillus fusiformis was also isolated from kolanut waste and plantation soil. It is a Gram-positive, non- motile, rod shaped bacterium of the genus Lysinibacillus. Priest et al. [52] reported it to have the ability to form inactive spherical endospore under strenuous condition to resist high temperature, damaging chemicals and ultraviolent light. Prior to 2007, Lysinibacillus fusiformis was originally known as Bacillus fusiformis when it was reclassified to the genus Lysinibacillus along with its close relative Bacillus sphaericus [49]. The reassignment of the organism was due to the distinctive characteristics of Lysinibacillus fusiformis such as physiology, phylogeny and its peptidoglycan composition. Lysinibacillus fusiformis is a naturally occurring bacterium and different strains have been isolated from farm soil and factory waste water. It is known to be mesophilic, mildly alkaliphilic and halophilic growing best at temperature range of $17-37^{\circ} \mathrm{C}, \mathrm{pH}$ range of 6-9.5 and in $\mathrm{NaCl}$ concentration of 2-7\%. Priest et al. [52] made an important documentation about this particular organism indicating that it can only occur in a symbiotic relationship with certain species of spirochaete. From the metabolic standpoint, Lysinibacillus fusiformis and Lysinibacillus sphaericus can be regarded as been identical because the only known distinguishing factor is that Lysinibacillus fusiformis is positive for urease while the other is negative. Modern molecular biology and rapid advancement in computational science have led to the generation of nucleic acid sequence, bioinformatics tools and phylogenetic inference methods.

Phylogenetic analysis has played a significant role in microbiology, the emerging fields of phylogenomics and comparative genomics is helping researchers understand roles microorganisms play in the environment [53]. Phylogenetics was used to understand the pattern by which the isolated microorganisms were genetically related to each other and thus trace their ancestry and level of evolution (Fig. 2). The clades/monophyletic groups observed on the phylogenetic tree constructed for the bacterial isolates in the study indicated a higher level of relatedness among the isolates and also some degree of genomic divergence. One major factor that causes divergence of microorganisms from their ancestry linage is adaptive radiation. A simultaneous evolution in genetic and ecological diversity of a single linage results in multitude of new forms, especially when a change in environment creates new challenges, makes new resources and/or open new environmental niches [54]. Fietz et al. [55] reported that adaptive radiation has been argued to be the resultant effect of divergent selection for specialization, which is believed to be 
caused by differences in the resources available among habitats and from competition for resources within the habitat. In a research work on population divergence and gut microbial composition of marine fishes conducted by Fietz et al. [55], it was discovered that elevated divergence occurs not only in response to change in salinity or other related natural selection, but also correlates with the bacterial composition of the water. This gave a hint to the influence of the environment and what it contains on genetic divergence of living organisms generally.

\section{CONCLUSION}

Without doubt, some microorganisms can be used to replace some synthetic chemical products used in our environments, detrimental to man and the entire ecosystem at large. They can be used to sustain the dying ecosystem and reduce dependence on rapidly declining natural resources. It is time to explore these creatures for cleanup of the environment from toxic compounds, use as biocontrols instead of chemicals, source of enzymes and other important products beneficial to man. From the findings of this study, it is clear that soils and agricultural wastes harbors large variety of important microorganisms of value to man. It is suggestive therefore that researchers dwell more on these vast and abundant substrates for novel microorganisms and their metabolic products. Further work is required on this study to establish the function and complexity of the microbial community which will provide unprecedented opportunities to assess the gene regulation, gene expression, genomic potential and function in situ.

\section{REFERENCES}

[1] American Society for Microbiology Basic Research on Bacteria. "The Essential Frontier", Report on the American Society for Microbiology and National Institutes of Health Workshop, pp. 1-16, 2007.

[2] Antwis, R. E, Griffiths, S.M., Harrison, X. A., Aranega-Bou, P., Arce, A., Bettridge, A.S.,Brailsford, F. L., De Menezes, A. B, Devaynes, A., Forbes, K. M., Fry, E. L., Goodhead, I.B., Haskell, E., Heys, C., James, C., Johnston, S. R., Lewis, G.R., Macey, M.C., McCarthy, A., McDonald, J. E., Mejia-Florez, N. L., O'Brien, D., Orland, C., Pautasso, M., Reid, W.D.K., Robinson, H., Wilson, K. and Sutherland, W.J. "50 important research questions in microbial ecology", FEMS Microbiology Ecology, Vol. 93, Number 5, pp. 18-22, 2017.

[3] Michael, E. H., Clay, F., Matthew, R. P. and Brook, S. P. "Bacterial competition: surviving and thriving in the microbial jungle", Nature Reviews Microbiology, Vol. 8, Number 1, pp. 15-25, 2010.

[4] Robert, W. K., William, C.C., Robert, C., Hall, M., Jaeger, C. C., Lowe, I., McCarthy, J.J., Schellnhuber, H.J., Bolin, B., Dickson, N.M., Faucheux, S., Gallopin, G.C., Grübler, A., Huntley, B., Jäger, J., Jodha, N.S., Kasperson, R.E., Mabogunje, A., Matson, P., Mooney, H., Moore, B., O'Riordan, T. and Svedin, U. "Sustainability Science" American Association for the Advancement of Science, Vol. 292, Number 5517, pp. 641-642, 2001.

[5] Jukes T. H. and Cantor C. R. Evolution of protein molecules, Academic Press, New York, 1969.

[6] El-Bendary, M. A. "Bacillus thuringiensis and Bacillus sphaericus production biopesticides production", Journal of Basic Microbiology, Vol. 46, Number 2, pp. 158-170, 2006.

[7] Atlas, R. M. and Philp, J. Bioremediation: Applied Microbial Solutions for Real World Environmental Cleanup, American Society for Microbiology (ASM) Press, Washington, D. C, 2005.

[8] Rabah, A. B., Oyeleke, S. B., Manga, S. B., Hassan, L. G. and Ijah, U.J.J. "Microbiological and physicochemical assessment of soil contaminated with abattoir effluents in Sokoto metropolis, Nigeria", Science World Journal, Vol. 5, Number 3, pp. 1-4. , 2010.

[9] Ohba, M., Tsuchiyama, A., Shisa, N., Nakashima, K., Lee, D.H., Ohgushi, A. and Wasano, N. "Naturally occurring Bacillus thuringiensis in oceanic islands of Japan, Daito-shoto and Ogasawara-shoto", Applied Entomology and Zoology, Vol.37, , pp. 477-480, 2002.

[10] Madigan, M.T., Martinko, J. M., Dunlap, P.V and Clark, D.P. Brock Biology of Microorganisms. Prentice Hall, United States, 2005.

[11] Yasutake, K., Uemori, A., Kagoshima, K. and Ohba, M. "Serological identification and insect toxicity of Bacillus thuringiensis isolated from the island Okinoerabu-jima, Japan", Applied Entomology and Zoology, Vol.42, pp. 285-290, 2007.

[12] Staley, J.T., Gunsalus, R. P., Lory, S. and Perry, J. J. Microbial Life, Sunderland, Massachusetts: Sinauer Associates, Inc, 2007.

[13] Roh, J.Y., Choi, J.Y., Li, M.S., Jin, B.R. and Je, Y.H. "Bacillus thuringiensis as a specific, safe, and effective tool for insect pest control", Journal of Microbiology and Biotechnology, Vol. 17, Number 4, pp. 547-59, 2007.

[14] Steinhaus, E A. Principles of Insect Pathology: An Advanced Treatise. McGraw-Hill publications, New York, 2012. 
[15] Brar, S.K., Verma, M., Tyagi, R.D. and Surampalli, R.Y. "Bacillus thuringiensis proteases: Production and role in growth, sporulation and synergism", Process Biochemistry, Vol.42, pp. 773-790, 2007.

[16] Manzano, M., Giusto, C., Lacumin, L., Cantoni, C. and Comi, G. "Molecular methods to evaluate biodiversity in Bacillus cereus and Bacillus thuringiensis strains from different origins", Food Microbiology, Vol. 26, 2009, pp. 259-264.

[17] Bergey, D.H., Whitman, W.B., De, V.P., Garrity, G.M and Jones, D. The Firmicutes, Springer Dordrecht Heidelberg, London, 2009.

[18] Hoffmann, H., Stindl, S., Stumpf, A., Mehlen, A., Monget, D., Heesemann, J., Schleifer, K. H. and Roggenkamp, A. "Description of Enterobacter ludwigii sp. nov., a novel Enterobacter species of clinical relevance", Systematic and Applied Microbiology, Vol. 28, pp. 206-212, 2005.

[19] Paauw, A., Caspers, M. P., Schuren, F.H., Leverstein-van, M. A., deletoile, A., Montijn, R. C., Verhoef, J. and Fluit, A. C. "Genomic diversity within the Enterobacter cloacae complex", Public Libaray of Science, Vol. 3, Number 8, pp. 18, 2008.

[20] Mezzatesta, M. L., Gona, F and Stefani, S. "Enterobacter cloacae complex: clinical impact and emerging antibiotic resistance”, Future Microbiology, Vol. 7, Number 7, pp. 887-902, 2012.

[21] Gengmi, Li., Zonghai, Hu., Zeng, P., Zhu, B. and Wu, L. "Whole genome sequence of Enterobacter ludwigii type strain EN-119', isolated from clinical specimens" FEMS Microbiology Letters, Vol. 362, Number 7, pp. 033, 2015.

[22] Don, J. B and Farmer, J. J. Family Enterobacteriaceae in: Bergey's Manual of Systemic Bacteriology, Springer-Verlag, Springer, USA, 2001.

[23] Whitaker, J. O., Dannelly, H. K. and Prentice, D. A. "Chitinase in insectivorous bats", Journal of Mammalogy, Vol. 85, pp. 15-18, 2004.

[24] Macaskie, L. E., Empson, R. M., Cheetham, A. K., Grey, C. P. and Skarnulis, A. J. "Uranium bioaccumulation by a Citrobactersp. as a result of enzymatically mediated growth of polycrystalline HU02P04", Science, Vol. 257, Number 5071, pp. 782-784, 1992.

[25]Suwansrinon, K., Wilde, H., Sitprija, V. and Hanvesakul, R. "Enteris fever-like illness caused by infection with Citrobacter amalonaticus", Journal of the Medical Association of Thailand, Vol. 88, Number 6, pp. 837-840, 2005.

[26] Raikher, Y., Stepanov V. I., Stolyar S.V., Ladygina V. P., Balaev D. A., Ishchenko L.A and Balasiou M.
"Magnetic properties of biomineral particles produced by bacteria Klebsiella oxytoca" Physics of the Solid State, Vol. 2, Number 2, pp. 298-305, 2010.

[27] Tang, P., Hseu, Y. C., Chou, H.H., Huang, K.Y and Chen, S. C. "Proteomic analysis of the effect of cyanide on Klebsiella oxytoca". Current Microbiology, Vol. 60, Number 3, pp. 224-228, 2010.

[28]Lalucat, J., Bennasar, A., Bosch, R., Garcia-Valdes, E and Palleroni N.J. "Biology of Pseudomonas stutzeri", Microbiology and Molecular Biology Reviews, Vol. 70, Number 2, pp. 510-547, 2006.

[29] Zawadzka, A. M., Ronald, L. C. and Andrzej, J.P. "Pyridine-2,6-Bis(Thiocarboxylic Acid) Produced by Pseudomonas Stutzeri KC Reduces and Precipitates Selenium and Tellurium Oxyanions" Applied and Environmental Microbiology, Vol. 72, Number 5, pp. 3119-3129, 2006.

[30] Chen, I. C., Hill, J.K., Ohlemüller, R., Roy, D.B. and Thomas, C. D. "Rapid Range Shifts of Species Associated with High Levels of Climate Warming" Science, Vol. 333, pp. 1024-1026, 2011.

[31] Gorshkova, N. M., Ivanova, E. P., Sergeev, A. F., Zhukova, N.V., Alexeeva, Y., Wright, J. P., Nicolau, D. V., Mikhailov, V.V. and Christen, R. "Marinobacter excellens sp. nov., isolated from sediments of the Sea of Japan", International Journal of Systematic and Evolutionary Microbiology, Vol. 53, pp. 2073-2078, 2003.

[32] Luo, Y. J., Xie, B. S., Lv, X. L., Cai, M., Wang, Y. N., Cui, H. L., Cai, $\mathrm{H}$ and $\mathrm{Wu}, \mathrm{X} . \mathrm{L}$. "Marinobacter shengliensis sp. nov., a moderately halophilic bacterium isolated from oil-contaminated saline soil", Antonie van Leeuwenhoek. Vol. 107, Number 4, pp. 1085-1094, 2015.

[33]Shieh, W.Y., Jean, W.D., Lin, Y.T. and Tseng, M. "Marinobacter lutaoensis sp. nov., a thermotolerant marine bacterium isolated from a coastal hot spring in Lutao, Taiwan", Canadian Journal of Microbiology, Vol. 49, pp. 244-252, 2003.

[34] Lee, O. O., Lai, P. Y., Wu, H.X., Zhou, X. J., Miao, L., Wang, H. and Qian, P. Y. "Marinobacter xestospongiaesp. nov., isolated from the marine sponge Xestospongia testudinaria collected from the Red Sea" International Journal of Systematic and Evolutionary Microbiology, Vol. 62, Number, 8, 2012, pp. 1980-1985.

[35] Handley, K.M., He'ry. M. and Lloyd, J.R. "Marinobacter santoriniensis sp. nov., an arsenate-respiring and arsenite oxidizing bacterium isolated from hydrothermal sediment", International Journal of Systematic and 
Evolutionary Microbiology, Vol. 59, pp. 886-892, 2009.

[36] Bagheri, M., Amoozegar, MA., Didari, M., Makhdoumi-Kakhki, A., Schumann, P., Spro"er, C., Sa'nchez-Porro, C. and Ventosa, A. "Marinobacter persicussp. nov., a moderately halophilic bacterium from a saline lake in Iran" Antonie Van Leeuwenhoek, Vol. 104, Number 1, pp. 1-8, 2013.

[37] Gu, J., Cai, H., Yu, S.L., Qu, R., Yin, B., Guo, YF., Zhao, J.Y and Wu, X.L. "Marinobacter gudaonensissp. nov., isolated from an oil-polluted saline soil in a Chinese oilfield", International Journal of Systematic and Evolutionary Microbiology, Vol. 57, pp. 250-254, 2007.

[38] Nagel, M. and Andreesen, J. R. "Bacillus niacini sp. nov. a Nicotinate-Metabolizing Mesophile Isolated from Soil" International Journal of Systematic Bacteriology, Vol. 41, Number 1, pp. 134-139, 1991.

[39] Espinosa-Urgel, M., Salido, A. and Ramos, J. "Genetic Analysis of Functions Involved in Adhesion of Pseudomonas putidato Seeds", Journal of Bacteriology, Vol. 182, Number 9, , pp. 2363-2369. 2000.

[40] Shash, M. P. "An Application of Bioaugmentation Strategy to Decolorize \& Degrade Reactive Black Dye by Pseudomonas spp", International Journal of Environmental Bioremediation \& Biodegradation, Vol. 2, Number 2, pp. 50-54, 2014.

[41] Romano, J. and Kolter, R. " PseudomonasSaccharomyces Interactions: Influence of Fungal Metabolism on Bacterial Physiology and Survival", Journal of Bacteriology, Vol. 187, Number 3, pp. 940-948, 2005.

[42] Boopathi, E. and Rao, K.S. "A siderophore from Pseudomonas putida type A1: structural and biological characterization", Biochimica et Biophysica Acta, Vol. 1435, Number 1-2, pp. 3040, 1999.

[43] Rantsiou, K., Iacumin, L., Cantoni, C., Comi, G. and Cocolin, L. "Ecology and characterization by molecular methods of Staphylococcus species isolated from fresh sausages", International Journal of Food Microbiology, Vol. 97, Numbers 3, pp. 277-2842005.

[44] Lambert, L.H., Cox, T., Mitchell, K., Rosselló-Mora, R. A., Del Cueto, C., Dodge D. E., Orkand, P. and Cano, R.. J. "Staphylococcus succinus $\mathrm{sp}$. nov. isolated from Dominican amber", International Journal of Systemic Bacteriology, Vol. 48, Number 2, pp. 511-518, 1998.

[45] Hauschild, T., Sliżewski, P. and Masiewicz, P. "Species distribution of staphylococci from small wild mammals", Systemic and Applied. Microbiology, Vol. 33, Number 8, pp. 457-460, 2010.

[46] Nováková, D., Sedlácek, I., Pantůcek, R., Stetina, V., Svec, P. and Petrás, P. "Staphylococcus equorum and Staphylococcus succinus isolated from human clinical specimens" Journal of Medical Microbiology, Vol. 55, Number 5, pp. 523528, 2006.

[47] Hu, X., Fan, W., Han, B., Liu, H., Zheng, D., Li, Q., Dong, W., Yan, J., Gao, M., Berry, C., Yuan, Z. "Complete genome sequence of the mosquitocidal bacterium Bacillus sphaericus C3-41 and comparison with those of closely related Bacillus species", Journal of Bacteriology, Vol. 190, Number 8, pp. 2892-2902, 2008.

[48] Lacey, L.A. "Bacillus thuringiensis, Serovariety israelensis and Bacillus sphaericus for mosquito control" Journal of American Mosquito Control, Vol. 23, Number 2, pp. 133-163, 2007.

[49] Ahmed, I., Yokota, A., Yamazoe, A and Fujiwara, T. "Proposal of Lysinibacillus Boronitolerans Gen. nov. sp. nov., and transfer of Bacillus Fusiformis to Lysinibacillus Fusiformis Comb. nov. and Bacillus Sphaericus to Lysinibacillus Sphaericus comb. nov.", International Journal of Systematic and Evolutionary Microbiology, Vol. 57, Number 5, pp. 1117-1125, 2007.

[50] Chandan, R.C, White, C.H, Kilara, A. and Hui, Y.H. Manufacturing Yogurt and Fermented Milks, Blackwell Publishing, Ames, IA, 2006.

[51] Yoh, M. "Importance of Providencia species as a major cause of travelers' diarrhoea", Journal of Medical Microbiology, Vol. 54, Number 11, pp. 1077-1082, 2005.

[52] Priest, F. G., Goodfellow, M. and Todd, C. "A Numerical Classification of the Genus Bacillus". Journal of General Microbiology, Vol. 134, Number 7, pp. 1847-82, 1988.

[53] Oren, A., Hong, S.G., Ludwig, W., Foutnier, G., Gupta, R., Gene, R., Andam, C. P., Gogarten, J.P and Durnford, D.G. Molecular Phylogeny of Microorganisms, Caister Academic Press. 2010.

[54] Maclean, R. C. "Adaptive radiation in microbial microcosms. Journal of Evolutionary Biology", European Society for Evolutionary Biology, Vol. 18, pp. 1376-1386, 2005.

[55] Fietz, K., Hintze, C. O., Skovrind, M., Nielsen, T. K., Limborg, M.T., Krag, M.A.,Palsbøll, P.J., Hansen, L.H., Møller, P. R. and Gilbert, M.T.P. "Mind the gut: genomic insights to population divergence and gut microbial composition of two marine keystone species", Microbiome, Vol. 6, pp. 82, 2018. 